\title{
Were Cicero's Philippics the Cause of his Death?
}

"The survival of the Philippics imperils historical judgement and wrecks historical perspective". ${ }^{1}$ So the eminently quotable Sir Ronald Syme, and he is clearly right-but only partly. Our perspective on the 632 days between the assassination of Caesar and the assassination of Cicero is warped by forces even more powerful than the Philippics: aside from Cicero's writings, what survives to document this period is mostly history written by the winners, and they were not disposed to an impartial presentation of the facts. The notion that Cicero was killed on Antony's orders, and that he was killed in particular because of the Philippics, has a pedigree stretching back to our earliest sources. Modern historians have a tendency to accept this version of events uncritically; after all, it is vouched for by a variety of ancient witnesses, and it just makes sense. Cicero did oppose Antony in the Philippics, and passionately and memorably. Indeed, in the Call for Papers for the conference panel that lies behind this very volume, the organizers referred to "Cicero's [...] death at the hands of Marc Antony". ${ }^{2}$ But this long-standing and convenient story will not withstand scrutiny. I hope to show that the idea that Cicero died because of Mark Antony is, if not wrong, at least oversimplified.

It is true that the ancient sources are unanimous in ascribing Cicero's death to Antony's malign influence and his hatred of Cicero and the Philippics, and I will briefly present this evidence. But I will then argue that our reading of the Philippics as a canonical corpus is unhistorical for the year 43 BCE, the only year that matters for Cicero's death: Antony is not likely to have been reacting to the Philippics as we know them today. Furthermore, I will point out that the rift between Cicero and Antony could have been patched up, as were many such conflicts in the late Republic, and that the rhetoric of the Philippics was in any case insufficient to motivate Cicero's murder. Finally, and most importantly, I will interrogate the role of the young Octavian in Cicero's proscription. Octavian probably played an active part in Cicero's demise, a part which he was later at pains to cover up. Perhaps we cannot recover the story of Cicero's

\footnotetext{
1 Syme 1939, 146.

2 And they were simply nodding en passant to a consensus view; a legion of scholars with similar opinions could be summoned to testify to the same tale. Cf. e. g. Rawson 1994, $486\left(=C A H^{2}\right)$ : "Antony made sure that he [= Cicero], with his brother and nephew-and his son, but he was with M. Brutus and survived-were on the fatal list”.
}

๑ OpenAccess. (c) 2020 Thomas J. Keeline, published by De Gruyter. (cc) BY-NC-ND This work is licensed under the Creative Commons Attribution-NonCommercial-NoDerivatives 4.0 License. 
death 'wie es eigentlich gewesen', but we can at least get closer to 'wie es wahrscheinlich gewesen', and in the process we will see some of the deliberate distortions that underlie Cicero's later legacy. ${ }^{3}$

\section{The ancient sources on Cicero's death}

The ancient sources all point to Antony as the architect of Cicero's death, and many also refer to the Philippics. So, for example, in our earliest surviving account of Cicero's final moments, Livy as preserved in the pages of Seneca's Suasoriae, we read:

M. Cicero sub aduentum triumuirorum urbe cesserat pro certo habens, id quod erat, non magis Antonio eripi se quam Caesari Cassium et Brutum posse. Primo in Tusculanum fugerat, inde transuersis itineribus in Formianum ut ab Caieta nauem conscensurus proficiscitur. Vnde aliquotiens in altum prouectum cum modo uenti aduersi rettulissent, modo ipse iactationem nauis caeco uoluente fluctu pati non posset, taedium tandem eum et fugae et uitae cepit regressusque ad superiorem uillam, quae paulo plus mille passibus a mari abest, "Moriar" inquit "in patria saepe seruata". Satis constat seruos fortiter fideliterque paratos fuisse ad dimicandum; ipsum deponi lecticam et quietos pati quod fors iniqua cogeret iussisse. Prominenti ex lectica praebentique immotam ceruicem caput praecisum est. Nec satis stolidae crudelitati militum fuit: manus quoque scripsisse aliquid in Antonium exprobrantes praeciderunt. Ita relatum caput ad Antonium iussuque eius inter duas manus in rostris positum, ubi ille consul, ubi saepe consularis, ubi eo ipso anno aduersus Antonium quanta nulla umquam humana uox cum admiratione eloquentiae auditus fuerat. Vix attollentes lacrimis oculos humentes intueri truncata membra ciues poterant. ${ }^{4}$

Cicero had left the city at the arrival of the triumvirs, since he was certain-and in the event he was right-that he could no more be saved from Antony than Brutus and Cassius could be saved from Octavian. First he had fled to his Tusculan villa, then he set out cross-country to his estate at Formiae, where he intended to board a ship from Caieta. There he tried to set sail several times, but he was first brought back by unfavorable winds, then he himself couldn't stand the tossing of the ship in the blindly swirling swell, and at last he grew tired of both flight and life. Then he returned to the villa where he had been staying, which was a little more than a mile inland, and said, "I shall die in the fatherland that I have often saved”. It's generally agreed that his slaves had been bravely and faithfully pre-

3 Cf. von Ranke 1885 ( $1^{\text {st }}$ ed. 1824), vii: "Man hat der Historie das Amt, die Vergangenheit zu richten, die Mitwelt zum Nutzen zukünftiger Jahre zu belehren, beigemessen. So hoher Ämter unterwindet sich gegenwärtiger Versuch nicht; er will bloß zeigen, wie es eigentlich gewesen”. 4 Sen. Suas. 6.17 = Livy fr. 60 Weissenborn/Müller. Translations my own unless otherwise noted. Citations of Latin texts follow the editions in the Packard Humanities Institute corpus, citations of Greek those in the Thesaurus Linguae Graecae. Occasional orthographical changes have been made for consistency. 
pared to fight, but that he himself ordered the litter to be put down and his slaves to suffer in silence what cruel fate forced him to endure. He leaned out of the litter and offered up his neck unflinchingly and was beheaded. And that wasn't enough for the stupid cruelty of the soldiers: they cut off his hands as well, reproaching them for having written something against Antony. Thus Cicero's head was brought to Antony and at his command was placed between the two hands on the rostra, where once as consul, and often as an ex-consul, and indeed in that very year speaking against Antony, he had been heard with admiration such as has never been felt for any other human voice. The citizens of Rome could scarcely lift their eyes overflowing with tears to look upon his butchered limbs.

Antony is the sole cause of Cicero's death-not a word about the other two triumvirs-and the Philippics get a look-in with the reference to Cicero's hands being cut off and the mention of Cicero's speeches that very year against Antony.

Other authors are even more emphatic, like Velleius Paterculus:

Furente deinde Antonio simulque Lepido [...], repugnante Caesare, sed frustra aduersus duos, instauratum Sullani exempli malum, proscriptio. Nihil tam indignum illo tempore fuit, quam quod aut Caesar aliquem proscribere coactus est aut ab ullo Cicero proscriptus est. Abscisaque scelere Antonii uox publica est, cum eius salutem nemo defendisset, qui per tot annos et publicam ciuitatis et priuatam ciuium defenderat. ${ }^{5}$

Then as Antony and Lepidus raged madly [...] proscriptions, the wicked custom sanctioned by Sulla's precedent, were renewed, even though Octavian fought against it-but he fought in vain, being but one against two. Nothing was so unworthy at that time as the fact that Octavian was forced to proscribe anyone or that Cicero was proscribed by anyone. The voice of the people was cut off by Antony's wicked crime, when no one defended the safety of the man who for so many years had defended both the public safety of the state and the private safety of its citizens.

Not only is it Antony's fault, Velleius says, but it is all Antony's fault. ${ }^{6}$ Unlike in Livy, where Octavian and Lepidus simply go unmentioned, here Octavian is expressly absolved of responsibility, a theme we will soon return to. After this introduction to the proscriptions, Velleius' rhetoric will swell to a crescendo in the following sections as he apostrophizes Antony and condemns him in scathing language for this foul deed.

These sources can be multiplied: Plutarch, for instance, claims that Cicero's head and hands, with which he had written the Philippics, were chopped off at Antony's command (

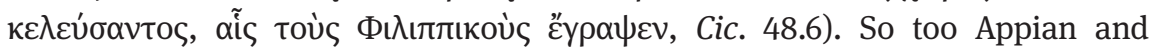

5 Vell. Pat. 2.66.1-2.

6 While Lepidus is mentioned as partly responsible for the proscriptions, it is Antony alone who is said to be responsible for Cicero's death. 
Cassius Dio and many others, like Martial and Juvenal. ${ }^{7}$ Indeed, the very premise of two of Seneca's Suasoriae-very popular topics-simply presupposes that Antony was Cicero's murderer and that the Philippics caused him to seek Cicero's death: "should Cicero beg Antony's forgiveness?” went one (deliberat Cicero an Antonium deprecetur, Suas. 6 pr.), and "should Cicero burn his writings if Antony agrees to spare his life?” went the other (deliberat Cicero an scripta sua comburat, promittente Antonio incolumitatem si fecisset, Suas. 7 pr.). ${ }^{8}$

So the ancient sources appear unanimous in agreeing that Antony was responsible, and indeed solely responsible, for Cicero's death. It might seem arrogant or even methodologically indefensible to argue that they have all got it wrong. But remember that we do not have the full picture, and remember further that most of our sources are not independent witnesses to the events they narrate: Livy and Pollio may be, and Tiro and Nepos and Augustus' own autobiography too, but those sources are either lost entirely or too fragmentary to be of much use. ${ }^{9}$ And even Livy was writing about Cicero's death long after Cicero died, perhaps as late as $13 \mathrm{CE}$, and Pollio too was looking back at a distance of at least a couple decades. ${ }^{10}$ Certainly the main extant sources-those from Velleius Paterculus and Valerius Maximus onwards-do not have much independent value. It is not unreasonable to wonder whether their story is a fair and unbiased account of Cicero's last days.

7 Other sources for Cicero's death include: Val. Max. 5.3.4; Sen. Controu. 7.2, Suas. 6, 7; Mart. 3.66, 5.69; Tac. Dial. 17; Juv. 10.114-132; Flor. 2.16; Plut. Cic. 46-49, Ant. 19.3, 20.2-4; App. B Ciu. 4.6, 19-20; Dio Cass. 47.8.3 -4, 11.1-2; Livy Per. 120; Oros. 6.18.10 -12; [Aur. Vict.] De uir. ill. 80.1. Cf. further Homeyer 1977; Roller 1997; Wright 2001; Keeline 2018, 102-146.

8 The theme of Cicero's death was wildly popular in declamation: the topic was declaimed in schools (Sen. Suas. 6.14, 7.12) and was equally well-known in Quintilian's day (Inst. 3.8.46). 9 For Tiro's biography of Cicero see McDermott 1972a, 282-284; FRHist 46. Nepos' biography is preserved only in frr. 37-38 Marshall; cf. FRHist 45. On Augustus' lost memoirs, see Smith and Powell 2009; FRHist 60.

10 For the date of Livy's writing on Cicero's death, cf. Lamacchia 1975, 434, who claims that Livy probably wrote book 120 (containing the death of Cicero) around 13 CE. The Periochae do note that book 121 was published after the death of Augustus (editus post excessum Augusti dicitur), although what this means for the composition and circulation of 120 is hard to say. Pollio had begun working on his history by the 20s BCE, as we can tell from Horace's Odes, but when he finished is unknown: FRHist $56=\mathrm{I} 436-438$. 


\section{In 43 BCE the 'Philippics' were not yet the Philippics}

We read the Philippics today as a unified corpus, which creates a certain sustained effect. So too were Romans reading a collection of Philippics at some point after Cicero's death. Already in Antiquity such a corpus was circulating, ${ }^{11}$ influencing the early perception and reception of the events of 44 and 43, and some part of this collection just may go back to Cicero himself. Gesine Manuwald, after a comprehensive review of the evidence, suggests that Cicero himself may have had the idea to publish Phil. 3-14 as a unified and coherent body, but she acknowledges that we cannot know how the corpus was structured when it was actually published, nor can we know when it was published or who published it. ${ }^{12}$ I think there are reasons to doubt that Cicero did publish any such collected edition, ${ }^{13}$ although certainty is admittedly impossible, and we do

11 Juvenal refers (circuitously) to Cicero's second Philippic, implying a numbered corpus (ridenda poemata malo | quam te, conspicuae diuina Philippica famae, | uolueris a prima quae proxima, 10.124-126). So too does Aulus Gellius cite the Philippics with 'our' numbering: 1.16.5, 1.22.17, 6.11.3, 13.1.1, 13.22.6. See Manuwald 2008, 40.

12 Manuwald 2008, 61. Bishop in this volume believes that Cicero "had a hand" in the publication of the Philippics and shaped Phil. 3-14 into a unified corpus (see p. 48).

13 Cicero delivered the fourteenth Philippic on 21 April (Phil. 14.14), and we know of a sixteenth and seventeenth still to come (from Arusianus Messius, late fourth century: GL VII 467.15-18; Manuwald 2007, 67-68, cf. also Eph. Tull. ad loc.). He was still delivering speeches against Antony in July (cf. Ad Brut. 1.15.10-11). So when would he have published his corpus? Given the speeches' exuberant praise of Octavian, it seems unlikely that they would have been issued in their present form after the break with Octavian, i.e. mid-August at the latest. If he included ' $15-17$ ' in the published corpus, it is hard to see why he did not wait until Antony had been decisively defeated to publish a definitive edition. If he really only published $3-14$, then why just those? (He delivered many other speeches around this time: Manuwald 2007, 70-72.) The justifications for these twelve often seem Procrustean: so perhaps the speeches held on 8, 9, and 14 April, on honors for L. Munatius Plancus, were not included as of "little relevance for the basic conflict with Antony" (Manuwald 2008, 47), but then why include the ninth Philippic, on honors for Servius Sulpicius Rufus (cf. Manuwald 2008, 55)? And it goes without saying that Cicero could not have been thinking about a fourteenth Philippic when he was delivering the third (so rightly Manuwald 2008, 45): these were real speeches designed to persuade real audiences of real ends, not elaborate exercises in imitatio and aemulatio. Last but perhaps not least, if Cicero only published 3-14, then we have to hypothesize a later editor who added 1-2 and 15-17, and another later redactor who removed 15-17 (or an accident of transmission or an error on the part of Arusianus Messius): not impossible, but it would certainly be simpler to have one editor publish all the Philippics that could be found. An obvious guess would be Atticus (cf. n. 16 below). 
know that he circulated at least some of his speeches against Antony after their delivery. ${ }^{14}$

What we can be confident about is that, whatever Antony was reading, his experience must have been far different from ours today. Why? In the first place, the preserved Philippics stretch from September 44 to April 43. Antony was only in Rome for the first Philippic, as he left for Gaul on November 28, 44, and did not return for a year. ${ }^{15}$ The second Philippic, which looms so large for reception ancient and modern alike, was circulated only among Cicero's closest friends, and may only have found a wide audience after his death ${ }^{16}$-even those who think that Cicero published a corpus of Philippics in his own lifetime usually restrict it to Phil. 3-14. While individual 'Philippics' circulated shortly after Cicero had delivered them, it seems hard to believe that Antony was receiving and reacting to accurate transcripts in real time when he had his hands full with military matters in Gaul. This is not to say that Antony was unaware of Cicero's opposition, of course, but merely to point out that he is unlikely to have reacted to perhaps patchy reports of speeches delivered in Rome over the course of many months the way we react to reading the unified corpus over a few days today. And even if Antony did read 3-14 as a body, they had not yet assumed their canonical importance. They would be one partisan salvo in a pamphlet war, nothing more ${ }^{17}$ indeed, their limited circulation in written form would have been secondary in importance to their public delivery. ${ }^{18}$ Cicero was hardly the only person

14 Phil. 5, 10, and 11: Ad Brut. 2.3.4, 2.4.2. There is no sure evidence for early circulation of the other speeches, although of course such circulation is possible. See Manuwald 2007, 60; 2008, 60.

15 Antony’s departure: Cic. Phil. 3.1-2, 11, 24, 31; 5.24; 13.20; App. B Ciu. 3.46; Dio Cass. 45.13.5, 20.4. His return, just before the passage of the Lex Titia (Nov. 27, 43): App. B Ciu. 4.7, Dio Cass. 47.1-2.

16 The publication of the second Philippic is entrusted to Atticus (Att. 15.13.1), with the explicit proviso that the speech is not to see the light of day until the Republic has been restored (quae non sit foras proditura nisi re publica recuperata, Att. 15.13 A.3); cf. 16.11.1-2 for Cicero's revision of the speech in light of Atticus' suggestions. See Manuwald 2007, 59 for full details and scholarly bibliography.

17 A war whose pro-Antony partisans have disappeared into historical oblivion: see Sillett in this volume; further Borgies 2016.

18 Cf. the fragment of Pollio's Pro Lamia, a speech perhaps given in December of 42 (Treggiari 1973, 250), quoted by Seneca the Elder (Suas. $6.15=O R F^{4}$ II 519, translated in-text below): itaque numquam per Ciceronem mora fuit quin eiuraret suas [esse] quas cupidissime effuderat orationes in Antonium; multiplicesque numero et accuratius scriptas illis contrarias edere ac uel ipse palam pro contione recitare pollicebatur. Whatever the status of the 'written' speeches (perhaps referring to individual speeches circulated singly; there is certainly no reference to a 'collection' or 'Phil- 
giving speeches and taking stands, even if he looms so large for us because of accidents of survival. The political situation at Rome was fluid and ever-shifting, and Antony's calculus, based on whatever intelligence he could get, must have been complex. In fact, by the time Antony could have read any hypothetical collected edition of the Philippics, it may have been clear that Cicero's cause was lost. ${ }^{19}$

And yet already in Antiquity later authors seem to assume that Antony would have been reading and reacting to the Philippics the same way that they were. ${ }^{20}$ These later authors would have studied the Philippics in the rhetorical school, and such intensive reading at a tender age doubtless made a lasting impression. ${ }^{21}$ But this impression should not be projected back onto Antony. In 43 BCE, the Philippics had not yet been canonized, and, whatever their written form, their distribution must have been relatively limited; we might reasonably doubt which of them Antony had even read. We should note further that this limited distribution would have made it all the easier for Cicero to change his position later, if he had wanted or needed to. While it may seem impossible to us, reading the canonized fourteen Philippics today, that Cicero could have changed his mind, at a time before these texts were known to every schoolboy a volte-face was much more plausible.

\section{The rift between Cicero and Antony could have been repaired}

We can go further: even if Antony was reading the Philippics with the ink still wet on the papyrus, the rift between him and Cicero still could have been repaired. They had a history of cordial relations that they could have drawn on: after the Ides of March, Cicero can write to Tiro mentioning that he of course would like to

ippics' here: cf. $\mathrm{n} .14$ above), public recitation in a contio is considered the more potent form of dissemination.

19 Bishop in this volume (p. 38) well notes that "it is manifestly odd that these speeches have been taken as evidence for Cicero's persuasive power, since any historical accounting of the period would underscore their distinct failure to persuade a number of figures: Octavian, Lepidus, frequently even the Senate itself. The primary group these speeches have persuaded, in fact, has been later readers, and by making the Philippics the epitome of Cicero's divine eloquence, they have situated a paradox at the center of his reception: immortal success that is predicated on an evident failure".

20 Cf. the references collected in n. 7 above.

21 Cf. Keeline 2018, 102-146. 
retain his "longstanding friendship with Antony, in which there has never been a hint of a quarrel" (ego tamen Antoni inueteratam sine ulla offensione amicitiam retinere sane uolo, Fam. 16.23.2, end of May [?] 44). He makes a similar comment to D. Brutus in early December of 44: "I was always his friend until I learned that he was waging war on the Republic" (cui quidem ego semper amicus fui ante quam illum intellexi [...] cum re publica bellum gerere, Fam. 11.5.2). ${ }^{22}$ Indeed, we learn from Phil. 12 that even in March 43, after some ten Philippics had already been delivered, Cicero was under serious consideration to be a member of an embassy to Antony: the senators at least must have thought his presence could serve the cause of peace. With a decade or more of amicitia behind them, a reconciliation between Antony and Cicero was surely not just possible but plausible.

Switching sides, moreover, would not have been a new thing for Cicero. This was the man who could pen a savage invective against Piso in 55 and try to ally himself with the senior consular eleven years later. He could attack Vatinius in scathing terms and oppose him for years, only to turn around and defend him when it seemed more expedient. He could hate Aulus Gabinius for helping to engineer his exile, and defend him when Pompey persuaded him to do so. He could go to war with Caesar and seek his forgiveness; praise his clemency and praise his death. Now times change, and people change with them. It is perhaps unfair to criticize Cicero on this score, and yet already in Antiquity he was notorious for his supposed inconstancy, and his apparent flip-flopping is one of the most common points of censure in the later tradition. So, for example, in the pseudo-Sallustian Invective, Cicero is called "a most fickle man, a suppliant to his enemies, reproachful to his friends, now on this side and now on that, loyal to no one, a most capricious senator, an advocate for hire" (homo leuissimus, supplex inimicis, amicis contumeliosus, modo harum, modo illarum partium, fidus nemini, leuissimus senator, mercennarius patronus, Inu. in Cic. 5). The author of the invective continues in this vein for two more paragraphs, summing up by calling Cicero a "faithless deserter, loyal neither to this side nor that" (leuissime transfuga, neque in hac neque in illa parte fidem habens, Inu. in Cic. 7). ${ }^{23}$ Cicero, of all people, knew how to accommodate himself to changed political realities.

22 Antony did serve as a prosecutor during Milo's trial (Asc. 41C, Mil. 40), but Cicero claims that Antony had sought out his friendship before that time (sum cultus a te, Phil. 2.49), and any breach of amicitia in 52 had been repaired by 49: Att. 10.8A.1.

23 Val. Max. 4.2.4 takes lemons and makes lemonade, praising Cicero's humanitas in laying aside old hatreds: Sed huiusce generis humanitas etiam in M. Cicerone praecipua apparuit: Aulum namque Gabinium repetundarum reum summo studio defendit, qui eum in consulatu suo urbe expulerat, idemque P. Vatinium dignitati suae semper infestum duobus publicis iudiciis tuta- 
But Cicero was hardly alone in being willing to switch alliances. Indeed, in the dying days of the Republic this behavior was standard. For example, until 58 Clodius and Pompey seem to have been on good terms. Then, seemingly out of the blue, Clodius turns on him viciously, perhaps even trying to have him assassinated. ${ }^{24}$ The hostility reaches a palpable peak when a mob led by Clodius tries to drown out Pompey with their shouts as Pompey spoke in defense of Milo at a trial in February of $56 .{ }^{25}$ Two months later came the conference at Luca, after which Pompey and Clodius are suddenly the best of friends. ${ }^{26}$ It is almost superfluous to pile up examples of this kind of behavior, but consider just Messalla Corvinus: he was proscribed by the triumvirs in 43, but escaped and made his way to Brutus. After Philippi he went over to Antony, but he ultimately switched sides again and allied himself with Octavian. In 27 his career culminated in an imperially sanctioned triumph. ${ }^{27}$ And such a man felt able to call Quintus Dellius, who went from Dolabella to Cassius to Antony to Octavian, the "horse jumper of the civil wars” (desultorem bellorum ciuilium, Sen. Suas. 1.7)! ${ }^{28}$

If the issue had just been a beef between Cicero and Antony, the conflict could have been patched up. Romans had heard a lot of scathing political invective in the 50s and 40s, including from Cicero himself: think again of Piso. And as in the case of Piso and so many others, Cicero could have changed his position, and perhaps he could even have sung a public palinode. Indeed, Asinius Pollio claimed that Cicero would have taken back his Philippics and published pro-Antony tracts if Antony had spared his life:

tus est, ut sine ullo crimine leuitatis, ita cum aliqua laude, quia speciosius aliquanto iniuriae beneficiis uincuntur quam mutui odii pertinacia pensantur. Such praise is the exception; cf. e.g. Sen. Controu. 2.4.4 (Julius Bassus): nemo sine uitio est: [...] in Cicerone, constantia.

24 Good terms: Plut. Pomp. 46.4, Cat. Min. 31.2. The abrupt breach: see the evidence and discussion in Tatum 1999, 166-168, Seager 2002, 103-104, 179-180.

25 Cic. Q.fr. 2.3.2, Plut. Pomp. 48.7.

26 Cf. e.g. Cic. Har. resp. 51, from May of 56. On the conference at Luca see e.g. Luibheid 1970. 27 Messalla made a virtue of necessity: "I was always on the better and more just side" ( $\varepsilon y \omega ́$ to

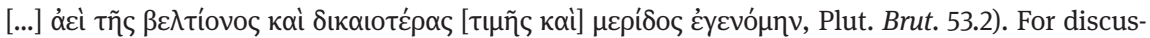
sion of Messalla's life, see Welch 2009, 200-205.

28 This list can be extended quite a bit; one more well-documented example is L. Munatius Plancus, who served with Caesar but favored amnesty for his assassins; he then successively sided with the Senate against Antony, with the triumvirs (even giving up his brother in the proscriptions), with Antony, and finally (before Actium) with Octavian. It was he who in 27 moved in the Senate that Octavian be called Augustus. For references and bibliography, see Toher 2017, 317-318. 
Itaque numquam per Ciceronem mora fuit quin eiuraret suas [esse] quas cupidissime effuderat orationes in Antonium; multiplicesque numero et accuratius scriptas illis contrarias edere ac uel ipse palam pro contione recitare pollicebatur. ${ }^{29}$

Therefore Cicero never hesitated an instant to reject under oath the speeches which he had eagerly poured out against Antony; he kept promising that he would issue more and better written speeches to the opposite effect, and that he would even recite these himself at a contio.

Was this true? Seneca doubts it, but it at least shows that the idea was plausible. Indeed, elsewhere Seneca himself says quite plainly that it is plausible, allowing that Cicero would have at least countenanced the idea of burning his books in return for forgiveness if the chance had been presented to him:

Huius suasoriae alteram partem neminem scio declamasse; omnes pro libris Ciceronis solliciti fuerunt, nemo pro ipso, cum adeo illa pars non sit mala ut Cicero, si haec condicio lata ei fuisset, deliberaturus non fuerit. ${ }^{30}$

I know of no one who took the other side in this Suasoria; everyone was concerned for Cicero's books, no one for Cicero himself, although the other side wasn't so bad that Cicero, if this condition had been offered to him, wouldn't have considered it.

Thus Cicero's contemporaries and near-contemporaries believed that Cicero could have recanted, and Cicero's history of changing his mind when circumstances changed was well known, and indeed hardly unique to him. To put claims of inconstancy aside, this was-and is-just good politics.

We should remember that Antony was willing to make common cause with Octavian after Octavian had been dispatched by the Senate with an army to track Antony down and kill him, and this would be only one instance in a long series of fallings out and forgivenesses between the two before the fatal final conflict. ${ }^{31}$ So too could he reconcile with Lepidus under similar circumstances. ${ }^{32}$ If we think that Antony arranged Cicero's murder in a fit of pique, because he was emotional, irrational, and blinded by hatred, we sell short his ability to make judgments about what was in his own best interests-and we acquiesce in the facile estima-

29 Pollio ap. Sen. Suas. 6.15 (= $O R F^{4}$ II 519).

30 Suas. 7.10.

31 Cf. e.g. the assassination plot in late 44 described below, or Antony's and Octavian's reconciliation at Brundisium ca. September of 40, when Antony agrees to marry Octavia (App. B Ciu. $5.59-65)$.

32 The case of Lepidus is slightly more complex, as Lepidus may have been playing both sides all along: evidence and discussion in Weigel 1992, 53-66. 
tion of Antony and his motives that the eventual Augustus was only too eager to promote.

\section{Octavian's not that innocent}

Of course you may object that everything I have mentioned so far is a bit circumstantial: maybe Antony really was just mad at Cicero and wanted his head. It is certainly true that Antony cannot have been happy with Cicero in late October of 43, but remember again how easily he made his peace with Octavian. It is time for us to look more closely at the proscriptions, and at Octavian's role in them.

We have already seen that Antony is universally blamed for Cicero's death in our ancient sources. The corollary of this universal condemnation is that Octavian is always acquitted of responsibility. Consider, for example, Plutarch:

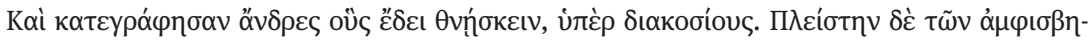

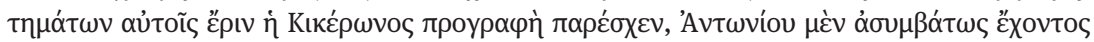

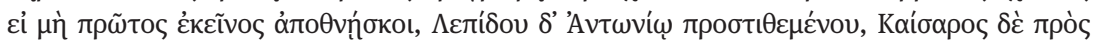

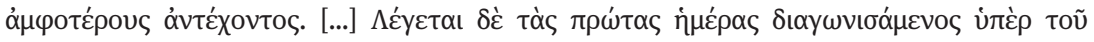

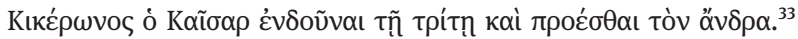

They made out a list of men who must be put to death, more than two hundred in number. The proscription of Cicero, however, caused the most strife in their debates, Antony consenting to no terms unless Cicero should be the first man to be put to death, Lepidus siding with Antony, and Octavian holding out against them both. [...] It is said that for the first two days Octavian kept up his struggle to save Cicero, but yielded on the third day and gave him up.

Some writers go further: Cassius Dio, for example, excuses Octavian from almost any role in the proscriptions (47.7.1) and even claims that he "saved as many as

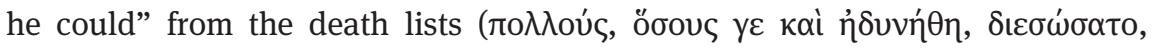
47.8.1). ${ }^{34}$ In his own Res Gestae, Augustus draws a veil of silence over the proscriptions. ${ }^{35}$ He would gladly have them consigned to oblivion.

But other opinions can be uncovered. Tacitus, for example, in successive paragraphs famously reports judgments exonerating and excoriating Octavian's

33 Cic. 46.2-5; cf. Flor. 2.16.1.

34 For the propaganda of these accounts, see Scott 1933, 19-20 and Borgies 2016, 147-158; on Appian and Dio, Gowing 1992a, 255-258.

35 In the Res Gestae Augustus in fact emphasizes his clemency to the defeated in the civil wars (Mon. Anc. 3): bella terra et mari ciuilia externaque toto in orbe terrarum suscepi uictorque omnibus ueniam petentibus ciuibus peperci. 
part in the proscriptions (Ann. 1.9.3-4, 1.10.2). ${ }^{36}$ Seneca the Younger contrasts the gentleness of the mature Augustus with his cruelty as an eighteen-year-old, when he murdered his friends, made an attempt on Antony's life, ${ }^{37}$ and was a partner in the proscriptions (duodeuicesimum egressus annum, iam pugiones in sinum amicorum absconderat, iam insidiis $M$. Antonii consulis latus petierat, iam fuerat collega proscriptionis, Clem. 1.9.1; cf. 1.11.1). ${ }^{38}$ Rumors swirled that it was Octavian who had killed the consuls Hirtius and Pansa, ${ }^{39}$ and Suetonius knows several stories of Octavian's savagery during the proscriptions (Aug. 27.1-2): ${ }^{40}$ although he held out against Antony and Lepidus at first, Suetonius reports, he was more cruel than either of them once the proscriptions had begun. He even proscribed his own former tutor, C. Toranius. ${ }^{41}$ And when the proscriptions were done, while Lepidus promised clemency in the future, Octavian said that he had only agreed to end the proscriptions on the condition that he could institute them again. Suetonius knows other tales from this time too:

Et Quintum Gallium praetorem, in officio salutationis tabellas duplices ueste tectas tenentem, suspicatus gladium occulere, nec quicquam statim, ne aliud inueniretur, ausus inquirere, paulo post per centuriones et milites raptum e tribunali seruilem in modum torsit ac fatentem nihil iussit occidi, prius oculis eius sua manu effossis; quem tamen scribit colloquio petito insidiatum sibi coniectumque a se in custodiam, deinde urbe interdicta dimissum naufragio uel latronum insidiis perisse. ${ }^{42}$

When Quintus Gallius, a praetor, held some folded tablets under his robe as he was paying his respects, Octavian, suspecting that he had a sword concealed there, did not dare to make a search on the spot for fear it should turn out to be something else; but a little later he had Gallius hustled from the tribunal by some centurions and soldiers, tortured

36 For ambivalent attitudes toward Augustus from Antiquity to the present, see Goodman 2018b.

37 Cf. Plut. Ant. 16.7; further Scott 1933, 8-10; Borgies 2016, 111-122.

38 On the passages from Seneca see Malaspina 2004, 292-316 ad loc.; 2009, 188-208 ad loc.; Berno 2013, 182-186; Green 2018, 51-56.

39 Tac. Ann. 1.10.2, Suet. Aug. 11, Dio Cass. 46.39.1. A countervailing pro-Augustan tradition was also in circulation (cf. App. B Ciu. 3.75-76); see further Wardle 2014, 126-127; Borgies 2016, 132 139.

40 On the striking absence of Cicero from Suetonius' account of the proscriptions, see McDermott 1972b.

41 Nicolaus of Damascus (Ex. 2.3) reports that Octavian's guardians squandered his money; this account may derive from an attempt of Octavian's to justify his proscription (cf. e.g. Borgies 2016, 155-156). But as Toher 2017, 174-175 notes, "there is no evidence that Octavian was ever in difficult financial straits", and so if this is self-justification, it is likely a fabrication along conventional lines (appointed guardians are notoriously unreliable stewards).

42 Aug. 27.4 = FRHist 60 fr. 14, from 43 or 42 BCE; cf. App. B Ciu. 3.95. Translation Rolfe 1914 with modifications. 
him as if he were a slave, and though he made no confession, ordered his execution, first tearing out the man's eyes with his own hand. He himself writes, however, that Gallius made a treacherous attack on him after asking for an audience and was haled off to prison; and that after he was dismissed under sentence of banishment, he either lost his life by shipwreck or was waylaid by brigands.

Here note that Octavian is not only craven and cruel, but moreover concerned to conceal the evidence of his misdeeds. Now of course an accusation need not necessarily imply guilt, and perhaps Octavian is simply defending himself from slander, but the real point is that such a charge is believable. This is the kind of thing that the young Octavian might have done. ${ }^{43}$ As Karl Galinsky writes, "the literature about [Octavian's] conspicuous cruelty at the time is ample and would not have taken off, even to the point of extensive exaggeration, if there had not been some truth at its core". ${ }^{44}$

So we have plenty of evidence, if we needed it, that Octavian was intimately involved with the proscriptions, and moreover that he was at pains later to cover up these early displays of suspicious and self-interested Realpolitik. We also know, of course, that this was a man obsessively concerned with image management. In his early years he gladly remitted tax and tribute payments to curry favor with the people and shunt blame onto Antony and Lepidus (Dio Cass. 49.15.4). Later he did not scruple to stop the publication of the acta senatus (Suet. Aug. 36.1) and to destroy 2000 books of prophetic oracles (Suet. Aug. 31.1). Indeed, in 36 BCE he is said to have arranged the burning of all docu-

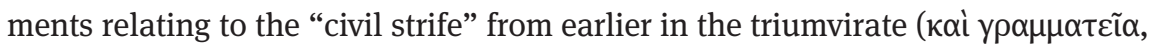

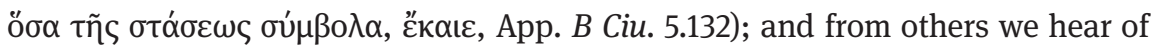
further book burnings years later (Sen. Controu. 10 pr. 5, Dio Cass. 56.27.1). ${ }^{45}$ And this is to say nothing of the use of images and monuments and literature. ${ }^{46}$ Octavian was an extremely canny manipulator of his own legacy.

43 Consider too Octavian's notorious cruelty after the siege of Perusia: see most graphically Suet. Aug. 15, Dio Cass. 48.14.4-5, and the implications of Sen. Clem. 1.11.1 (Perusinas aras); cf. App. B Ciu. 5.49. Augustus may have been reacting to these reports in his Autobiography (FRHist 60 fr. 8): see Powell 2009, 180 -181; the apologetic tenor of the Autobiography more generally is clear (e.g. Powell 2009, 174). On the Gallius incident see further Wardle 2014, 210 -212. 44 Galinsky 2012, 35.

45 On book burnings see Howley 2017.

46 Cf. e.g. Zanker 1988; Galinsky 1996; Beacham 2005; Levick 2010, 115-163; Petersen 2015, 57-66. Augustan influence might extend even into funeral orations: for the Laudatio Turiae as a piece of Augustan propaganda, see Gowing 1992b. On the propaganda of the conflict between Antony and Octavian, see Scott 1933 and esp. Borgies 2016. For a defense of the term 
You might think that Cicero would not fit in very well with that legacy. After all, Octavian prided himself on "avenging his father's murderers" (qui parentem meum necauerunt, eos in exilium expuli iudiciis legitimis ultus eorum facinus et postea bellum inferentes rei publicae uici bis acie, Mon. Anc. 2). This was the whole point of the Lex Pedia, which at a stroke enabled the trial and condemnation of the Caesaricides, enshrining this version of events in the official record. ${ }^{47}$ Now Cicero did not stab Caesar, it is true, but only because he had not been invited to join the conspiracy. He wished that he had been (quam uellem ad illas pulcherrimas epulas me Idibus Martiis inuitasses, Fam. 10.28.1 [to Trebonius], sim. 12.4.1). ${ }^{48}$ Once Caesar was dead, Cicero stood firmly on the side of the Liberators. Indeed, the Liberators knew this from the first: when Brutus drew his bloody dagger from Caesar's corpse, he called out to Cicero by name and congratulated him on the restoration of libertas to the Republic (Phil. 2.28, 30). Cicero and Octavian thus stand on opposite sides of one of Octavian's most important personal and political issues.

And what about Cicero's political ideology more generally? The mature Cicero was a conservative, a man who believed in the Roman constitution. He was by this time deeply distrustful of extraordinary imperium and extraconstitutional arrangements. ${ }^{49}$ His Philippics stand not just as an invective against Antony, but even more so as a monument against tyranny-of any sort. ${ }^{50} \mathrm{He}$ is fairly obsessed with restoring libertas to the Republic and decrying seruitus and dominatio. Here is an instance plucked almost at random from the corpus:

Quapropter, quoniam res in id discrimen adducta est, utrum ille poenas rei publicae luat, an nos seruiamus, aliquando, per deos immortales, patres conscripti, patrium animum uirtutemque capiamus, ut aut libertatem propriam Romani et generis et nominis reciperemus aut mortem seruituti anteponamus. ${ }^{51}$

'propaganda', see Levick 2010, 10 -12; Galinsky 1996, 39-41 and Pandey 2018, 6-8 are more cautious about the word's modern connotations.

47 Cf. e.g. Vell. Pat. 2.69.5, Plut. Brut. 27.4-5, Suet. Ner. 3.1-2, App. B Ciu. 3.95, Dio Cass. 46.48.1-49.5.

48 His joy at Caesar's death, and various justifications for it, are often expressed. Cf. e.g. Att. 14.14.5: si licuerit, libertatem esse recuperatam laetabor; si non licuerit, quid mihi attulerit ista domini mutatio praeter laetitiam quam oculis cepi iusto interitu tyranni?

49 Cf. e.g. Phil.11.17: extraordinarium imperium populare atque uentosum est, minimeque nostrae grauitatis, minime huius ordinis. At other times and in other circumstances Cicero could admittedly make other accommodations; cf. e.g. Leg. Man. and Prou. cons., but the deep-seated conservativism of the consular Cicero seems clear.

50 Cf. Bishop in this volume.

51 Phil. 3.29. 
Therefore, since matters have come to this critical moment to decide whether Antony will pay the penalty to the Republic or we will be slaves, at long last-by the immortal gods!-let us take up our ancestral courage and manhood, conscript fathers, so that we either retake the rightful liberty of the Roman people and of the name of Rome, or else choose death before slavery.

For Cicero, moreover, libertas meant freedom from the dominion of a tyrant, whether that tyrant was named Antony or Octavian or took the form of a new "three-headed monster". ${ }^{22}$ This political philosophy would thus have been just as inconvenient to the ambitious Octavian as it was to Antony. Occasionally we can even glimpse a recognition of this in the ancient sources: Plutarch writes that Octavian stopped courting Cicero when he realized that Cicero was firmly

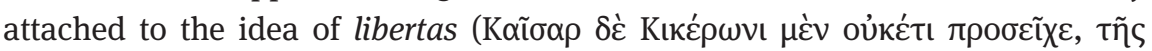

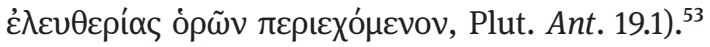

These philosophical disagreements had practical consequences in 43 BCE, leading ultimately to a falling out between Octavian and Cicero. ${ }^{54}$ Cicero initially thought that he could control-or, to be more charitable, 'mentor'-the young Octavian. ${ }^{55}$ In the summer of 43 , Cicero seems even to have floated the idea of a shared consulship, but the proposal foundered for lack of senatorial backing. ${ }^{56}$ Octavian then marched on Rome, and in so doing he forfeited Cicero's support. Cassius Dio reports how one of Octavian's soldiers brandished his sword in the Senate House and said, "If you don't give the consulship to Octavian, this

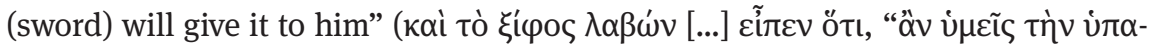

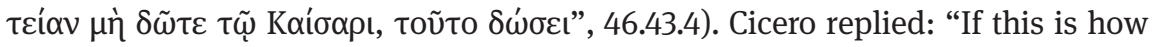

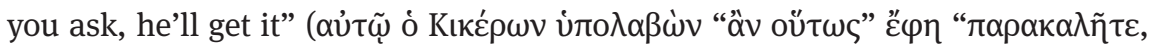

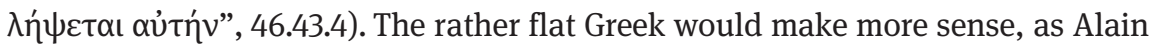
Gowing has pointed out, in a Latin version with ambiguity between sword (gla-

52 For extensive discussion of libertas in the late Republic, see Wirszubski 1950 and Arena 2012.

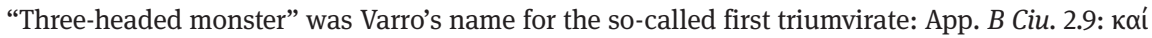

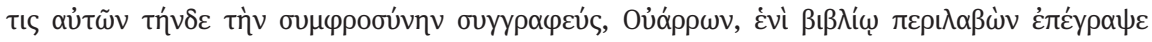
Tpıкópavov.

53 Further discussion of the Plutarch passage in Pelling 1988, 164-165.

54 Cicero's occasional snide remarks about Octavian cannot have helped matters either. So his infamous quip about how Octavian was "to be praised, honored-and given the push" (ipsum Caesarem nihil sane de te questum nisi dictum, quod diceret te dixisse laudandum adulescentem, ornandum, tollendum; se non esse commissurum ut tolli possit, Cic. Fam. 11.20.1 [from D. Brutus]; further Vell. Pat. 2.62.6, Suet. Aug. 12). Cf. too the depreciatory references to Octavian as puer, discussed in McCarthy 1931.

55 For evidence and discussion, see Achard 1981, 178-183 and Bellen 1985 with Gotter 1996, $275-276$.

56 Plut. Cic. 45.5-6 with Moles 1988, 197; cf. App. B Ciu. 3.92, Dio Cass. 46.42.2, Plut. Cic. 44.1. 
dius) and consulship (consulatus). ${ }^{57}$ Dio concludes darkly that "this remark

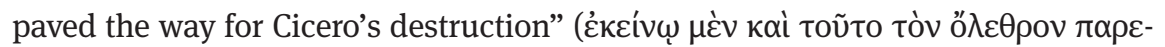

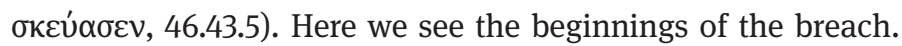

Cicero himself seems to have been nervous after the consular pact failed: Appian claims that he disappeared from Rome around this time, presumably out of fear (B Ciu. 3.89). But when Octavian marched on Rome to commandeer the consulship, Cicero returned, for there was a brief resurgence of resistance to the coming tyranny. Fresh legions had arrived from Africa, and the Senate resolved to fight and to choose, as Cicero had so often urged, death before slavery. They hoped it would not come to that; indeed, they hoped that in a fight for freedom Octavian's soldiers would defect to their cause. But senatorial resistance crumbled as soon as Octavian himself appeared near the Quirinal Hill. The African legions went over to Octavian, and any hope of stopping him seemed stamped out (App. B Ciu. 3.90-92).

Cicero then sought an interview with Octavian through mutual friends, and in that interview tried to defend himself. Octavian cryptically and mockingly replied that Cicero "seemed to be the last of his friends to greet him" (ó $\delta \dot{\varepsilon}$ тoбoũ-

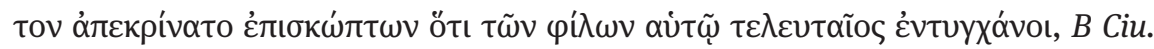
3.92). Cicero was not reassured. The next day rumors began to swirl that two of Octavian's legions had gone over to the Republicans, and Cicero was again to be found among the assembled senators trying to organize forces to fight Octavian. The rumors were false, and Cicero fled Rome once more (B Ciu. 3.93).

Can the details of these stories in Appian and Dio be trusted? Perhaps not, although I do think Dio's potential Latin pun sounds very much like Cicero. ${ }^{58}$ But what is beyond doubt is this: when Octavian marched on Rome and demanded the consulship, he lost Cicero's support, and he knew it. Cicero was actively resisting his designs. Octavian and Cicero had thus fallen out already in mid-August of 43, more than two months before the formation of the triumvirate.

When Octavian did obtain the consulship on August 19, Cicero knew full well that he had made a powerful enemy. He remained outside Rome and outside the political spotlight. His last preserved snippet of correspondence acknowledges the new superiority of that enemy, and seems to show a willingness to go along to get along:

57 Gowing 1992a, 152 n. 30.

58 The reliability of the stories hinges on two issues that cannot be discussed here: (1) What were Appian's and Dio's sources? and (2) What use did they make of these sources? For these questions see esp. Gowing 1992a, 39-50; on Appian's sources and methods, see more recently Rich 2015 and Westall 2015; for Dio, see the essays in part II of Fromentin et al. 2016. 
Quod mihi et Philippo uacationem das, bis gaudeo; nam et praeteritis ignoscis et concedis futura. ${ }^{59}$

The fact that you grant me and Philippus (= L. Marcius Philippus, Octavian's step-father) a dispensation (sc. from attending Senate meetings) makes me doubly happy, for you show forgiveness for the past and mercy for the future.

After months of resistance, Cicero now meekly implies that he will accommodate himself to yet another change of political circumstances. ${ }^{60}$ He is acutely conscious that he has made an enemy of Octavian and done things requiring forgiveness, and he hopes that Octavian's gesture of granting him a dispensation from attending the Senate is a sign of merciful treatment to come. It was not.

In late October or early November the triumvirs met on an island in the middle of a river near modern Bologna and drew up their proscription list. It featured some 2000 equites and 300 senators, Cicero among them. ${ }^{61}$ Our sources, as we have seen, insist that Octavian resisted the proscriptions and resisted Cicero's inclusion among the proscribed-it was, they say, Antony's fault. But when Antony, Lepidus, and Octavian convened on that island, they haggled and made their ghoulish bargain alone. ${ }^{62}$ Any report of their deliberations must go back to one of these three men, or else simply be invented out of whole cloth. We can be quite sure that it was not Antony who promulgated the memory of his own savagery. Which of the three triumvirs had a massive interest in defending Octavian and slandering Antony? Octavian himself, of course. Augustus may well have presented this bit of self-justification in his Autobiography, or perhaps he had let it be known earlier in other ways.

In late 43, Cicero was as much Octavian's enemy as he was Antony's. But as the years rolled on and Antony and Octavian had their own falling out, Octavian found in Cicero a convenient ally and a convenient story. ${ }^{63}$ Cicero had indeed bitterly opposed Antony in the Philippics, and he had moreover piled panegyric upon Octavian in those same speeches. Thus it was not hard to re-fashion Cicero

59 Ad Caes. iun. fr. 23B Watt; cf. also Eph. Tull. ad loc.

60 Or so it appears, at any rate; the text is fragmentary and without more context no reconstruction can be absolutely certain.

61 Numbers as reported in App. B Ciu. 4.5. Hinard 1985, 264-269 suspects a lower total, perhaps around 300; see his monograph for details on the proscriptions more generally, including a prosopography of known victims. In less detail cf. Biava 2004 (who agrees with Hinard about the number of victims on p. 331).

62 For their solitude, see App. B Ciu. 4.2; cf. Dio Cass. 46.55.2.

63 A story that Lepidus fades out of as the conflict between Antony and Octavian becomes allimportant. 
into a martyr in the struggle against Antony, and in so doing to co-opt Cicero's powerful voice and cultural authority to Octavian's anti-Antony cause. Such a reworking of history also could help excuse Octavian's role in the proscriptions: those were all Antony's fault. ${ }^{64}$ In a quirk of history, then, Cicero's legacy was suddenly useful to Octavian-and so he retroactively changed sides, claiming that he had supported Cicero all along. Cicero thus became a proto-Augustan.

The Revised Authorized Version did not catch on right away: people doubtless remembered the reality of the proscriptions, and it took time for those people to die out or for their memories to fade. ${ }^{65}$ Augustan poets nowhere mention Cicero explicitly-perhaps it was 'too soon' or too dangerous to take a side on Cicero's legacy in those early years. ${ }^{66}$ And even long after Cicero's death, one of Augustus' grandsons was terrified when Augustus found him reading some book of Cicero's. But Augustus sought to reassure him: "An eloquent man, my

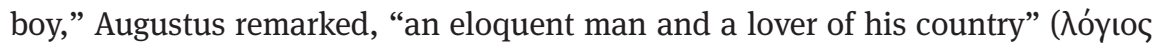

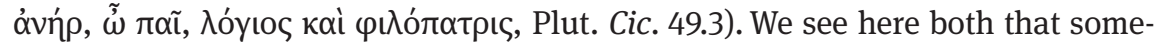
one might fear being found out as a Ciceronian, and that Augustus was concerned to have Cicero on his side as a good Roman patriot. Moreover, after Antony had been defeated once and for all at Alexandria, Octavian made M. Tullius Cicero fils his co-consul in 30, where he had the honor of announcing Antony's death from the rostra (Plut. Cic. 49.6, App. B Ciu. 4.51). ${ }^{67}$ Octavian had earlier made him a pontifex; in Appian's words, "to apologize for his betrayal of Cicero"

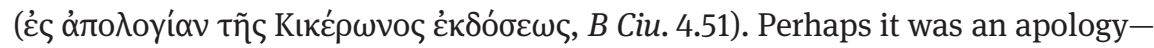
or perhaps it was another savvy bit of Realpolitik to get Cicero's own son to agree with the Gospel according to Octavian. ${ }^{68}$

These were certainly not the only attempts to appropriate Cicero's legacy for the Augustan regime. Augustus would, for example, use the coincidence of his birth in the consulship of Cicero as a powerful piece of propaganda. Indeed, Octavian was supposedly born in the midst of a Senate discussion of the very Cat-

64 Early imperial declamation picked up on this Augustan line for a complex set of reasons: see Keeline 2018, 110.

65 And, to change the metaphor, for the wounds on the body politic to heal.

66 Cf. Sillett in this volume on possible allusions to Cicero in the Aeneid.

67 I think this event more likely an instance of Octavian's supremely self-conscious image management rather than a piece of later myth-making, but the latter cannot be ruled out.

68 On other consuls from 'the opposition', see Welch 2009, 195 n. 2. Welch persuasively argues that "the new Princeps had every reason to desire reconciled Republicans to join him in recounting the past, just as he encouraged them to participate in the re-formed government”. Thus Augustus was able to persuade a variety of former enemies to subscribe to his version of events. 
ilinarian conspiracy that Cicero so famously suppressed (Suet. Aug. 94.5)!69 Other authors pick up on this happy coincidence too (e.g. Vell. Pat. 2.36.1, Plut. Cic. 44.7). But perhaps the most notable example of Augustus' co-opting Cicero's memory is found in his Autobiography, where he recounts a supposed dream of Cicero's:

Reformatorem imperii, puerulum adhuc et priuatum loci, et Iulium Octauium tantum et sibi ignotum Marcus Tullius iam et Augustum et ciuilium turbinum sepultorem de somnio norat. In uitae illius ${ }^{70}$ commentariis conditum est. $^{71}$

In a dream Cicero recognized the reformer of the Empire, still a boy with no part in public life, just Julius Octavius and unknown to Cicero, already as Augustus and the burier of civil strife. This story's found in his (sc. Augustus') autobiography.

Cicero is here made into a prophet of Augustus' future greatness, a fully paid-up supporter of the Augustan regime from its glorious leader's earliest years: this is propaganda plain and simple. Finally, one might well wonder why we have none of the letters between Octavian and Cicero, and indeed no letters at all from the last five months of Cicero's life, the time when he must have fallen out with Octavian-the coincidence is at least very suspicious. ${ }^{72}$

Augustus wanted Cicero on his side, and any inconvenient truths about his proscription had to be hushed up. Perhaps Augustus first began telling this tale in his self-justifying Autobiography, or perhaps he let it be known in other ways. Whatever its original source, the congenial fiction that Antony alone was responsible for Cicero's proscription quickly engulfs the entire tradition surrounding Cicero's death, probably propagated especially through declamation, which endlessly repeated the story of Cicero's last days and hours. And so the Augustan version of events, downplaying Octavian's role in Cicero's demise and reclaiming Cicero's memory in the service of Augustus' own regime, took hold and has never let go.

69 This is almost certainly impossible; Augustus was born September 23, and the Senate is not known to have discussed the conspiracy until October 21: see Wardle 2014, 517-519, and Eph. Tull. ad loc.

70 uitae illius Vossius : uitelliis MSS. Vossius' emendation is almost universally accepted; for full justification, see Wiseman 2009, 111-112.

71 FRHist 60 fr. 4 = Tert. Anim. 46.7, cf. Plut. Cic. 44.3-7, Suet. Aug. 94.9, Dio Cass. 54.2.2-4. 72 Perhaps it is merely an accident of transmission, of course, and Nonius does preserve fragments of the letters to Octavian, but Weysenhoff 1966, 78 - 79 argues that these letters were never published and that Nonius' knowledge is second-hand, deriving perhaps from a Ciceronian word list compiled by Tiro; see too Nicholson 1998, 85-86. 


\section{Conclusion}

Cicero was, simply put, a potential problem for the whole triumvirate. They may well have been able to bring him around-Cicero had shown a willingness to accommodate himself before, and he could have done so again; indeed, he seemed perhaps already to be doing so. Changing sides was not particularly problematic, and in any case, he and Antony had been friends for years before this recent falling out, and the Philippics themselves would not have proved an insuperable obstacle in the year 43. Antony perhaps would not have liked him, but if Antony had been the only one against him, he probably could have gotten over his hurt feelings on the right terms-perhaps a public palinode from Cicero and a promise of future support. Remember, Antony got over Octavian and his army, a threat to his life and plans rather more concrete than the Philippics.

Octavian's motives to want Cicero out of the way were just as strong as Antony's: Cicero's political ideology, his attitude toward Caesar's death and the 'Liberators', his power and influence, his inconvenient status as a mentor whom Octavian had 'outgrown' and thrown over. By August of 43, after Octavian had seized the consulship by force, he and Cicero were no longer on the same side; indeed, Cicero was openly resisting him (and alternately begging forgiveness). When our sources tell us that Octavian held out against Cicero's proscription for days, we must be hearing Octavian's own self-justifying voice, and it seems plain that that voice doth protest too much.

There were further factors underlying Cicero's proscription that all the triumvirs could agree on. For example, they were united in using proscription as a sort of perverse fund-raising scheme, and many names were added to the list solely so that their lands could be confiscated..$^{73}$ Cicero may not have had a lot of liquidity, to use modern terminology, but he owned a variety of country villas and a house in Rome that he had bought for three and a half million sesterces: liquidation of Cicero immediately made his property assets liquid as well. ${ }^{74}$ Most importantly, the triumvirs all would have felt that Cicero's resolute backing of the free Republic against extra-constitutional arrangements would have been inconvenient, to say the least, if they were not able to get him on side.

Cicero's death thus solved a lot of problems for a lot of people all at once. Antony did not like him, to be sure, but Octavian was just as involved, and all three of the triumvirs signed the death warrant. In a strange twist, however,

73 A point well made by Syme 1939, 195. Cf. App. B Ciu. 4.5, Dio Cass. 47.6.5, and Gowing 1992a, 249-250.

74 Cicero's house went to a partisan of Antony's, L. Marcius Censorinus (Vell. Pat. 2.14.3). 
when Antony and Octavian finally and decisively clashed, the living Octavian found an unlikely ally in the dead Cicero. A decade after Cicero was killed, Octavian began exploiting this serendipitous coincidence for all he could to blacken Antony's memory and whitewash his own role in Cicero's death, reclaiming Cicero and his legacy for the Augustan regime. It was an amazingly successful rebranding campaign, and two millennia of reception have made it seem not only the way it was, but indeed the only way it could have been. It is not, and we should look more closely. Cicero was not proscribed by Antony; he was proscribed by the triumvirate. ${ }^{75}$

75 I would like to thank Leanne Jansen, Christoph Pieper, and Bram van der Velden for organizing the conference panel where the original version of this paper was presented. Christoph and Bram have subsequently shepherded the conference papers through to publication with exemplary editorial care. I would also like to thank all the panel attendees for thought-provoking discussion and good fellowship. Finally, thanks to the general editor of this series, Ermanno Malaspina, who read through a near-final version of this paper with his expert eye and made a number of acute suggestions. 
